Гопчак І. В., к.геогр.н., доц. (Національний університет водного господарства та природокористування, м. Рівне), Яцик А. В., академік НАAН, д.т.н., проф. (Український науково-дослідний інститут водогосподарсько-екологічних проблем, м. Київ), Басюк Т. О., к.геогр.н (Міжнародний економіко-гуманітарний університет імені академіка Степана Дем'янчука), Семенко Л. 0., к.с-г.н., с.н.c. (Інститут водних проблем і меліорації НААН України, м. Київ)

\title{
НАУКОВІ ОСНОВИ ВСТАНОВЛЕННЯ ЕКОЛОГІЧНО ДОПУСТИМИХ РІВНІВ ВІДБОРУ ВОДИ 3 МАЛИХ РІЧОК
}

Розроблені розрахункові моделі визначення допустимих рівнів відбору води з річок дають змогу визначити мінімальні витрати води, які необхідно залишити в річці в кожну фазу гідрологічного режиму 3 метою збереження безпечного і стійкого стану водної екосистеми. Сформульовані основні вимоги до вибору об'єктів дослідження, визначення розрахункових ділянок і формування блоків вихідних даних забезпечують єдиний підхід до організації програми досліджень і підготовки бази вихідної інформації. Відповідно до методики об'єм екологічного стоку, який необхідно залишити в річці для збереження сталого функціонування річкової екосистеми, становить $40 \%$ норми стоку. Методологія забезпечує врахування у розрахунках значного числа вагомих гідрологічних та гідробіологічних чинників, аналіз численних варіантів природних і антропогенних впливів на річкові екосистеми та отримання обґрунтованої оцінки екологічно допустимих мінімальних витрат води, які необхідно резервувати в річці в різні фази водного режиму для збереження сталого функціонування річкової екосистеми. Впровадження результатів досліджень у практику природоохоронної і водогосподарської діяльності дозволить науково обґрунтувати рівень водокористування при якому, не підриватиметься здатність природних комплексів до саморегуляції, самоочищення і самовідновлення Ключові слова: річка, відбір води, рівень води, витрата води, гідрологічний режим, басейн річки.

Постановка проблеми. За умов ненормованих відборів води і зарегульованості стоку екосистеми ряду річок України, особливо ма- 
лих, функціонують переважно у середньомаловодних умовах, а у весняний період у виключно маловодних. Проточність річок при цьому зменшується, зменшується і самоочисна їх здатність. Якість води погіршується. Більшість заплав, які мають велике значення для відтворення рибних запасів, водоплавної птиці, високих врожаїв лучних трав, а також виконують роль бар'єру забрудненим стокам з поверхні водозбору, осушені. Все це призвело до загострення екологічної ситуації і падіння біологічної продуктивності екосистем.

Відсутність екологічних нормативів для визначення екологічно допустимих мінімальних витрат води в річках створює великі труднощі в проектній, водогосподарській і водоохоронній практиці. Значна частина публікацій [1-8], у тому числі і зарубіжних, базується в основному на власному баченні окремих аспектів проблеми, які не доведені до логічного завершення. Тому на сьогодні немає спільного єдиного бачення основ розрахунку зазначених витрат і відповідних об'ємів води. За таких обставин виникає нагальна потреба розробити і ввести обмеження на відбори поверхневого стоку навіть на тих річках, де вони не перевищили екологічно допустимі.

Мета роботи полягає в розробці методології встановлення екологічно допустимих рівнів відбору води з малих річок.

В практиці українського водогосподарського проектування за санітарні витрати води приймається середньомісячна витрата води 3 забезпеченістю її зберігання в річці 95\%. Цій умові відповідає найменша середньомісячна витрата води в маловодному році, що повторюється один раз за 20 років. Визначення таких санітарних витрат води нічим не обґрунтовано і, може привести при їх дотриманні до незворотних змін в екосистемах. Це розуміють і провідні фахівці проектних і наукових установ, про що свідчить розроблена методика [9].

У роботі [10] концептуально представлена методика встановлення в річці природоохоронного стоку. Крім загально відомих положень, конкретних пропозицій немає.

У Керівництві [11] відносно водоохоронного стоку (де він називається екологічним) сказано, що такий стік повинен забезпечувати дотримання самоочисної здатності водотоку; незамулення, незаростання русла; обводнення прируслових територій; задоволення потреб водокористувачів по об'єму і якості води, а також задоволення потреб, які пред'являють природоохоронні організації як до самої річки, так і до водоприймача. Мінімальна екологічна витрата води враховується, як водокористувач без вилучення води з джерел. Багато 3 цих положень вірні. Однак деякі не розкриті і, на наш погляд хибні. 
Також тут відсутня розрахункова основа, без якої все вище сказане можна віднести до переліку факторів, які обумовлюють екологічний стік.

Виклад основного матеріалу. Основною умовою при виконанні оцінки екологічно допустимих рівнів відбору води з річок $є$ збереження екологічно безпечного стану водної екосистеми, коли зміни структурно-функціональної організації екосистеми не підриватимуть здатність природних комплексів до саморегуляції, самоочищення та самовідтворення. При зростаючому рівні антропогенного втручання збереження сталого функціонування річкової екосистеми залежить від пошуку та встановлення лімітуючих факторів і розрахункових критеріїв, які обумовлюють обмеження такого втручання.

Аналізуючи функціонування річкових екосистем в природних умовах було встановлено, що річки - це складні динамічні біокосні системи, яким притаманні циклічність фаз водного режиму, біопродуктивність, присутність постійного зв'язку з біоценозами суші та внутрішньоводного трофічного ланцюгу. На підставі цього було виділено основні фактори, які лімітують здатність екосистеми річок до самовідтворення (рисунок). Проте, головними факторами, які обумовлюють в екосистемі її самоочисну здатність $€$ режим розчиненого у воді кисню та баланс процесів продукції і деструкції органічної речовини. Кисневий режим водотоку в свою чергу визначає безпечні умови життєдіяльності біоти та рівень окислювальновідтворювальних процесів, а баланс процесів продукції і деструкції виступає підсумковим інтегральним показником стану екосистеми.

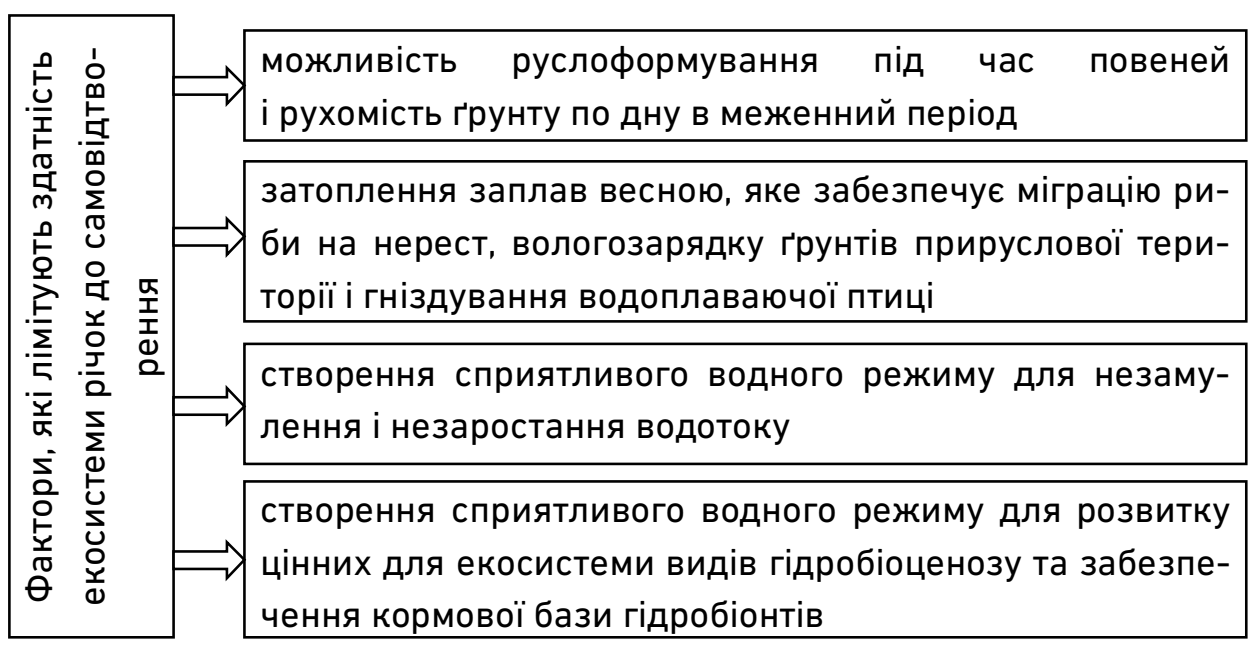

Рисунок. Основні фактори, які лімітують здатність

екосистеми річок до самовідтворення 
Отже, зазначені фактори обумовили методичний підхід до визначення екологічно допустимих рівнів відбору води з річок за еколого-гідрологічними показниками та балансом процесів продукції і деструкції. Виходячи з цього, можливо більш обґрунтовано оцінити екологічно допустимі мінімальні витрати води, які необхідно резервувати в річці в різні фази гідрологічного режиму для збереження сталого функціонування річкової екосистеми.

Даний методичний підхід не суперечить теоретичному положенню про наявність в складних динамічних природно-географічних структурах «опорних механізмів», що контролюють прямі і зворотні зв'язки між різними компонентами природного середовища. Наявність в «опорних механізмах» так званих вузлових ланок дозволяє оцінити стан екосистеми та керувати ними. Екологічно допустимі мінімальні витрати води є «опорним механізмом» при визначенні рівнів відбору води з річок, а вузловими ланками виступають екологічно значимі елементи гідрологічного режиму i продукційнодеструкційних процесів у річці.

Аналіз факторів, які обумовлюють збереження сталого функціонування річкових екосистем показали, що задача визначення екологічно допустимих рівнів відбору води з річок $є$ багатокритеріальною. Вибір критеріїв екологічно безпечного відбору стоку з річок здійснений згідно встановлених факторів і загальної концепції, за якою річки розглядаються як водні екосистеми, складені з абіотичних та біотичних компонентів.

Основними критеріями при цьому є: гідрологічні, екологічні, санітарно-гігієнічні, водогосподарські та інші. Головними критеріями, що потребують розрахункових оцінок, є: 1) гідрологічні, у тому числі ті, що забезпечують самовідтворення річкової екосистеми; 2) екологічні, зокрема ті, що визначають параметри процесів природного самоочищення і стану біоти в екосистемі.

Ключовими процесами, параметри яких мають визначати екологічно допустимий рівень відбору стоку з річки, визначено: процеси руслоформування і створення сприятливого гідрологічного режиму для річкових екосистем; процеси первинної продукції і деструкції органічної речовини.

До показників, за якими оцінюватимуться процеси руслоформування і формування сприятливого гідрологічного режиму, що лімітують величини відбору води з річок в різні фази водного режиму, віднесено наступні:

1) рівні і витрати води у весняну повінь, дотримання яких за- 
безпечує у річках переміщення донних і завислих наносів та можливість руслоформування, затоплення заплав і вологозарядку ґрунтів прируслової території, міграції риби на нерест відновленню кормів для всіх видів гідробіонтів;

2) режим швидкості течії руслового потоку на початку вегетації макрофітів, розвитку фіто- і зоопланктону, який сприяє створенню оптимальних умов формування гідробіоценозів та пригнічує розвиток синьозелених водоростей;

3) критичні незамулюючі середні швидкості течії руслового потоку, дотримання яких забезпечує рухомість ґрунту по дну;

4) критичні середні швидкості течії руслового потоку в період інтенсивного розвитку макрофітів, величини яких перешкоджають заростанню водного дзеркала.

Зокрема, до показників, за якими оцінюватиметься перебіг продукційно-деструкційних процесів у екосистемах малих річок, визначено:

1) біомаса фітопланктону (з врахуванням біомаси бентосних водоростей, що виноситься з річковим стоком);

2) рівень насичення води розчиненим киснем, погіршення якого призводить влітку до уповільнення процесів самоочищення, а взимку - до заморів риби;

3) рівень вмісту біологічно-м'яких органічних сполук автохтонного і алохтонного походження за інтегральним показником БСК повн.

Останні два показники є нормованими для всіх категорій водних об'єктів України та всіх видів стічних вод.

На розрахункових ділянках враховуватимуться: вплив приток; вплив скидів стічних вод; вплив заборів води для водогосподарських потреб.

Для оцінки екологічно допустимих рівнів відбору води з річок за еколого-гідрологічними критеріями за розрахункові періоди прийнято всі фази водного режиму року, а для оцінки рівня продукційно-деструкційних процесів - літню і зимову межень.

Відповідно до визначених еколого-гідрологічних показників, за якими створюються умови для збереження сталого функціонування річкових екосистем, розрахунковими критеріями $є$ наступні:

1. Рівень виходу води на заплаву в період повені і відповідна витрата води, при значенні яких відбувається затоплення заплави шаром необхідним для міграції риби на нерест і вологозарядка ґрунтів прируслової території для забезпечення росту лучних трав;

2. Руслоформуюча витрата води (у межах русла), проходження 
якої збільшує транспортуючу здатність водного потоку, що зумовлює промивання русла і можливість руслоформування;

3. Швидкісний режим водного потоку, за яким передбачається наявність у річці критичних швидкостей течії, за значенням яких русло не замулюється $\left(V_{\text {нз }}=0,1-0,25 \mathrm{~m} / \mathrm{c}\right)$, не заростає $\left(V_{\text {зар }}=0,3 \mathrm{~m} / \mathrm{c}\right)$ і при яких створюються найбільш сприятливі умови для формування цінних для екосистеми видів гідробіоценозів $\left(V_{4}=0,5-0,6 \mathrm{M} / \mathrm{c}\right)$.

Перші два критерії визначають екологічно допустимі витрати води в екстремальний період повені, коли створюються умови для затоплення заплав і транспортування наносів. Аналізуючи стік території України встановлено, що у більшості випадків майже в усіх її природних зонах такий період повені на малих річках припадає на березень.

Критерії швидкісного режиму руслового потоку лімітують екологічно допустимі мінімальні витрати води взимку, навесні (квітеньтравень) та в літньо-осінню межень.

Навесні швидкість течії в річці суттєво впливає на розвиток ценозів. За даними режимних спостережень встановлено, що на території України перехід температури води через $10^{\circ} \mathrm{C}$ припадає в основному на квітень, коли рівень сонячного випромінювання достатній для фотосинтезу. В цей період починається вегетація макрофітів та інтенсивний розвиток водоростей, а з переходом температури води за $15^{\circ}$ С спостерігається максимум продуктивності синьозелених і зелених водоростей [12]. Створенню оптимальних умов для формування ценозів і пригнічення росту синьозелених водоростей у річках сприяє швидкість течії руслового потоку на рівні 0,5-0,6 м/с. За таких умов мінімальні витрати води в квітні не повинні бути меншими за ті, які забезпечують зазначені швидкості, а в травні - за ті, які перешкоджають заростанню водного дзеркала $\left(V_{\text {зар }}=0,3 \mathrm{M} / \mathrm{c}\right)$.

Узимку і в літньо-осінню межень екологічно допустимі мінімальні витрати води лімітуються незамулюючими швидкостями руслового потоку $V_{\text {нз. }}$

Для більшості річок їх значення змінюється залежно від природних зон в наступних межах:

- для зони Полісся з повільною течією річок $-V_{\text {нз }}=0,25-0,20$ м/с;

- для зони Лісостепу $-V_{\text {нз }}=0,20-0,15 \mathrm{~m} / \mathrm{c}$;

- для Степу - $V_{\text {нз }}=0,15-0,10 \mathrm{~m} / \mathrm{c}$.

Однак можуть бути і відхилення, особливо для дуже малих річок. Лише в лютому при надходженні в русла річок стоку з поверхні водозбору величина незамулюючої швидкості становить близько 


\section{$0,25 \mathrm{~m} / \mathrm{c}$.}

При визначенні екологічно допустимих рівнів відбору води з річок потрібно перш за все визначити згідно розрахункових критеріїв у заданому створі рівень виходу води на заплаву $H_{3}$, за залежністю $Q=f(H)$ та встановити відповідну йому витрату води $Q_{3}$, а за рекомендаціями, що наведені в роботі [13] - значення руслоформуючої витрати води $Q_{p \phi}$ в межах русла. Згодом на підставі даних стаціонарних спостережень підібрати річку-аналог з чітко вираженою повінню, водний режим якої характеризується проходженням в березні $H_{\text {макс }} \geq$ $H_{3}$ та $Q_{\text {макс }} \leq Q_{3}$. Якщо в період повені зазначеного аналога мала місце руслоформуюча витрата води в межах русла та була затоплена заплава відповідним шаром з наступним плавним спадом рівня води, то такий водний режим березня можна прийняти за екологічно допустимий. При цьому об'єм встановленого аналога повинен бути найменшим порівняно з іншими при заданому співвідношенні $\mathrm{H}_{\text {макс } \mathrm{i}}$

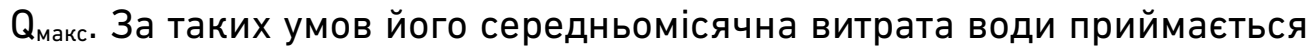
за екологічно допустиму в середньому за березень.

Для визначення екологічно допустимих мінімальних витрат води в розрахункових створах за критеріями швидкісного режиму необхідно за даними багаторічних вимірів гідрологічних і гідравлічних характеристик заданого періоду створити масив найменших витрат води, які спостерігались у водному потоці при всіх зафіксованих середніх швидкостей течії руслового потоку і на його основі побудувати залежності $Q=f(V)$.

У результаті отримуємо графічні і аналітичні залежності $Q=f(V)$, на підставі яких за розрахунковими критеріями можна встановити екологічно допустимі мінімальні витрати води, які необхідно залишати в річці для збереження сталого функціонування річкової екосистеми.

При побудові залежностей $Q=f(V)$ встановлено, що найбільш високі коефіцієнти кореляції $(0,85-0,98)$ мають залежності $Q=f(V)$ за грудень-січень, червень-серпень, вересень-листопад, дещо менші - за лютий, квітень і травень, тобто за місяці з нестійким водним режимом.

Тому, враховуючи сучасний рівень спостережень, зазначені залежності слід приймати за розрахункові. Проте при наявності достатньої кількості вихідних даних побудова $Q=f(V)$ здійснюється за кожний місяць окремо.

Розрахунки екологічно допустимих мінімальних витрат води здійснюються по сезонах року за такими розрахунковими періодами: 
- в зонах Полісся і Лісостепу - зима (XII-I і II), весна (III, IV,V), літо (VI-VIII), осінь (IX-XI);

- в зоні Степу - зима (XII-I), весна (II,III,IV), літо (V,VI-VIII), осінь (IX-XI).

Якщо в русло річки вище розрахункового створу надходять стічні води, де, як відомо, основну частку становлять органічні речовини, то мінімальні витрати води, які необхідні для нейтралізації цих вод і стабілізації кисневого режиму у воді річок, можна розрахувати за формулою Фелпса-Стриттера в модифікації Й. В. Гриба [14].

Усі показники, що застосовуються в методиці [11], достатньо інформативні та доступні для визначення лише за однією умовою, а саме - наявність матеріалів спостережень на водному об'єкті.

У разі їх відсутності необхідно провести польові обстеження розрахункової ділянки річки та зробити виміри, зокрема: 1) швидкості водного потоку; 2) витрат води (за можливістю); 3) рівнів і глибин по повздовжньому профілю і поперечних перерізах для застосування способу гідравлічного розрахунку витрат води за формулою ШезіСрібного [15].

Висновок. Отже, розроблені розрахункові моделі визначення допустимих рівнів відбору води з річок дають змогу визначити мінімальні витрати води, які необхідно залишити в річці в кожну фазу гідрологічного режиму з метою збереження безпечного і стійкого стану водної екосистеми. Сформульовані основні вимоги до вибору об' $\epsilon-$ ктів дослідження, визначення розрахункових ділянок і формування блоків вихідних даних забезпечують єдиний підхід до організації програми досліджень і підготовки бази вихідної інформації.

Аналізуючи розрахунки для окремих річок [16], встановлено, що визначений за розробленою методикою об'єм екологічного стоку, який необхідно залишити в річці для збереження сталого функціонування річкової екосистеми, становить 40\% норми стоку. В дуже маловодний рік 95\%-ної забезпеченості водні ресурси не забезпечують об'єми екологічного стоку і $W_{e}>W_{p}$, а в маловодний рік $75 \%$-ної забезпеченості його водні ресурси перебільшують екологічний стік на незначну величину. Проведені дослідження дають підставу вважати, що запропонована методологія забезпечує врахування у розрахунках значного числа вагомих гідрологічних та гідробіологічних чинників, аналіз численних варіантів природних і антропогенних впливів на річкові екосистеми та отримання обґрунтованої оцінки екологічно допустимих мінімальних витрат води, які необхідно резервувати в річці в різні фази водного режиму для збереження сталого фун- 
кціонування річкової екосистеми.

Проте складність зазначених розробок потребує удосконалення методичних рекомендацій і подальшої апробації на конкретних водних об'єктах. Впровадження рекомендацій у практику природоохоронної і водогосподарської діяльності дозволить науково обґрунтувати рівень водокористування при якому, не підриватиметься здатність природних комплексів до саморегуляції, самоочищення і самовідновлення.

1. Гатилло П.Д., Филипович И. М. Вопросы определения минимально необходимых расходов рек. Проблемы использования водных ресурсов. Минск : Наука и техника, 1971. С. 21-36. 2. Вендров С. Л. Изменение природных условий в речных долинах ниже гидроузлов и в устьях рек. Инженерно-географические проблемы проектирования и эксплуатации равнинных водохранилищ. М., 1972. С. 79-89. 3. Гайлюшис Б. В. Определение ненарушаемого расхода рек. Тр. АН Лит. ССР; Сер. Б. 1974. Т. 5(84). С. 121-125. 4. Петров Г. Н. Определение размера минимального допустимого остаточного речного стока ниже водозаборов и гидроузлов. Водоснабжение и санитария. 1974. № 4. С. 8-9. 5. Дерябин В. Н., Ширяк И. М. Оценка возможности водохозяйственного использования малых рек с учетом экологических особенностей. Проблемы рационального использования и охраны малых рек. Красноярск : Сиб. НИИГиМ, 1982. С. 126-132. 6. Фащевский Б. В. Методические основы оценки резервируемого природоохранного стока. Водные ресурсы Белоруссии и их охрана. Минск : Изд-во Белорус. Ун-та, 1982. С. 85-94. 7. Фащевский Б. В. Экологическое обоснование допустимой степени регулирования речного стока. Минск : ЦНИИ комплексного использования водных ресурсов, 1989. 60 с. 8. Каск А. Г., Васильєв А. А., Лоде З. А. Методика определения расчетных минимальных (лимитированных) расходов воды. Тр.ИПГ. 1988. Вып. 69. С. 93-101. 9. Методика визначення екологічно допустимих рівнів відбору води з річок з метою збереження сталого функціонування їх екосистем / А. В. Яцик, Л. Б. Бишовець, С. М. Кириченко та ін. К., 2002. 48 с. 10. Трегубенко В. Й. О природоохранных расходах водотоков Украины. К., 1993. 15 с. 11. Руководство по проектированию мероприятий по улучшению экологического состояния малых рек Украины Т-343: Этап 1 «Рекомендации по проектированию мероприятий по улучшению экологического состояния малых рек Украины». К., 1992. 36 с. 12. Водоросли : справ. / С. П. Вассер, Н. В. Кондратьева, Н. П. Масюк и др. Киев : Наук. думка, 1989. 608 с. 13. Малі річки України : довідник / А. В. Яцик, Л. Б. Бишовець, Є. О. Богатов та ін. ; за ред. А. В. Яцика. К. : Урожай, 1991. 296 с. 14. Гриб Й. В. Анализ заморных явлений в малых реках Западного Полесья. Гидробиол. журн. 1972. К. 2. С. 42-48. 15. Лебедев В. В. Гидрологические и водохозяйственные расчеты для проектирования сооружений водоснабжения. М. : Изд-во литературы по стр-ву, 1965. 396 с. 16. Холоденко В. С. Сучасні методики встановлення 
екологічно допустимих мінімальних витрат води на річках Прип'ятського Полісся України. Географія та туризм. 2012. Вип. 21. С. 241-249.

\section{REFERENCES:}

1. Hatillo P. D., Filipovich I. M. Voprosy opredeleniia minimalno neobkhodimykh raskhodov rek. Problemy ispolzovaniia vodnykh resursov. Minsk : Nauka i tekhnika, 1971. S. 21-36. 2. Vendrov S. L. Izmenenie prirodnykh uslovii v rechnykh dolinakh nizhe hidrouzlov i v ustiakh rek. Inzhenerno-heohraficheskie problemy proektirovaniia i ekspluatatsii ravninnykh vodokhranilishch. M., 1972. S. 79-89. 3. Hailiushis B. V. Opredelenie nenarushaemoho raskhoda rek. Tr. AN Lit. SSR; Ser. B. 1974. T. 5(84). S. 121-125. 4. Petrov H. N. Opredelenie razmera minimalnoho dopustimoho ostatochnoho rechnoho stoka nizhe vodozaborov i hidrouzlov. Vodosnabzhenie i sanitariia. 1974. № 4. S. 8-9. 5. Deriabin V. N., Shiriak I. M. Otsenka vozmozhnosti vodokhoziaistvennoho ispolzovaniia malykh rek $s$ uchetom ekolohicheskikh osobennostei. Problemy ratsionalnoho ispolzovaniia i okhrany malykh rek. Krasnoiarsk. Sib. NIIHiM, 1982. S. 126-132. 6. Fashchevskyi B. V. Metodicheskie osnovy otsenki rezerviruemoho prirodookhrannoho stoka. Vodnye resursy Belorussii $i$ ikh okhrana. Minsk : Izd-vo Belorus. Un-ta, 1982. S. 85-94. 7. Fashchevskii B. V. Ekolohicheskoe obosnovanie dopustimoi stepeni rehulirovaniia rechnoho stoka. Mynsk : TsNII kompleksnoho ispolzovaniia vodnykh resursov, 1989. 60 s. 8. Kask A. H., Vasiliev A. A., Lode Z. A. Metodika opredeleniia raschetnykh minimalnykh (limitirovannykh) raskhodov vody. Tr.IPH. 1988. Vyp. 69. S. 93101. 9. Metodyka vyznachennia ekolohichno dopustymykh rivniv vidboru vody $z$ richok z metoiu zberezhennia staloho funktsionuvannia yikh ekosystem / A. B. Yatsyk, L. B. Byshovets, S. M. Kyrychenko ta in. K., 2002. 48 s. 10. Trehubenko V. I. O prirodookhrannykh raskhodakh vodotokov Ukrainy. K., 1993. 15 s. 11. Rukovodstvo po proektirovaniiu meropriiatii po uluchsheniiu ekolohicheskoho sostoianiia malykh rek Ukrainy T-343: Etap 1 «Rekomendatsii po proektirovaniiu meropriiatii po uluchsheniiu ekolohicheskoho sostoianiia malykh rek Ukrainy». K., 1992. 36 s. 12. Vodorosli : sprav. / S. P. Vasser, N. V. Kondrateva, N. P. Masiuk i dr. Kiev : Nauk. dumka,1989. 608 s. 13. Mali richky Ukrainy : dovidnyk / A. V. Yatsyk, L. B. Byshovets, Ye. O. Bohatov ta in. ; za red. A. V. Yatsyka. K. : Urozhai, 1991. 296 s. 14. Hrib I. V. Analiz zamornykh yavlenii v malykh rekakh Zapadnoho Polesia. Hidrobiol. zhurn. 1972. K. 2. S. 42-48. 15. Lebedev V. V. Hidrolohicheskie i vodokhoziaistvennye raschety dlia proektirovaniia sooruzhenii vodosnabzheniia. M. : Izd-vo literatury po strvu, 1965. 396 s. 16. Kholodenko V. S. Suchasni metodyky vstanovlennia ekolohichno dopustymykh minimalnykh vytrat vody na richkakh Prypiatskoho Polissia Ukrainy. Heohrafiia ta turyzm. 2012. Vyp. 21. S. 241-249. 
Gopchak I. V., Candidate of Geographical Sciences (Ph.D.), Associate Professor (National University of Water and Environmental Engineering, Rivne); Yatsyk A. V., Academic NAAS, Doctor of Engineering, Professor (Ukrainian Research Institute of Water Management and Ecological Problems, Engineering Lane, Kyiv); Basiuk T. O., Candidate of Geographical Sciences (Ph.D.) (International University of Economics and Humanities, Academician Stepan Demianchuk, Rivne);

Semenko L. O., Candidate of Agricultural Sciences (Ph.D.), Senior Research Fellow (Institute of Water Problems and Land Reclamation NAAS of Ukraine, Kyiv)

\section{SCIENTIFIC BASES FOR ESTABLISHING ECOLOGICALLY ACCEPTABLE WATER ABSTRACTION LEVELS FROM SMALL RIVERS}

The design models for determining the admissible levels of water abstraction from rivers allow the determination of the minimum water flow rates that must be left in the river in each phase of the hydrological regime in order to maintain the safe and stable status of the aquatic ecosystem. The formulated basic requirements for the choice of research objects, the definition of computational sites and the formation of blocks of output data provide a unified approach to the organization of the program of research and preparation of the baseline information. According to the methodology, the amount of environmental runoff that must be left in the river to maintain the river ecosystem's sustainable functioning is $\mathbf{4 0 \%}$ of the runoff rate. The methodology provides for the consideration of significant number of significant hydrological and hydrobiological factors in the calculations, analysis of numerous variants of natural and anthropogenic impacts on river ecosystems and obtaining a reasonable estimation of the ecologically acceptable minimum water costs, which must be reserved in the river for different phases of water conservation. The introduction of research results into the practice of nature conservation and water management will allow to scientifically substantiate the level of water use in which the ability of natural complexes to self-regulation, self-purification and selfhealing will not be undermined.

Keywords: river, water abstraction, water level, water flow, hydrological regime, river basin. 
Гопчак И. В., к.геогр.н., доцент (Национальный университет водного хозяйства и природопользования, г. Ровно); Яцык А. В., академик НААН, д.т.н., проф., (Украинский научно-исследовательский институт водохозяйственно-экологических проблем, г. Киев); Басюк Т. А., к.геогр.н. (Международный экономико-гуманитарный университет имени академика Степана Демьянчука, г. Ровно); Сэмэнко Л. О., к.с-Х.н., с.н.с. (Институт водных проблем и мелиорации НААН Украины, г. Киев)

НАУЧНЫЕ ОСНОВЫ УСТАНОВЛЕНИЯ ЭКОЛОГИЧЕСКИ ДОПУСТИМЫХ УРОВНЕЙ ОТБОРА ВОДЫ ИЗ МАЛЫХ РЕК

Разработанные расчетные модели определения допустимых уровней отбора воды из рек позволяют определить минимальные расходы воды, которые необходимо оставить в реке в каждую фазу гидрологического режима с целью сохранения безопасного и устойчивого состояния водной экосистемы. Сформулированы основные требования к выбору объектов исследования, определение расчетных участков и формирование блоков исходных данных обеспечивают единый подход к организации программы исследований и подготовки базы исходной информации. Согласно методике объем экологического стока, который необходимо оставить в реке для сохранения устойчивого функционирования речной экосистемы, составляет $\mathbf{4 0 \%}$ нормы стока. Методология обеспечивает учет в расчетах значительного числа весомых гидрологических и гидробиологических факторов, анализ многочисленных вариантов природных и антропогенных воздействий на речные экосистемы и получения обоснованной оценки экологически допустимых минимальных расходов воды, которые необходимо резервировать в реке в разные фазы водного режима для сохранения устойчивого функционирования речной экосистемы. Внедрение результатов исследований в практику природоохранной и водохозяйственной деятельности позволит научно обосновать уровень водопользования при котором, не будет подрываться способность природных комплексов к саморегуляции, самоочищению и самовосстановлению.

Ключевые слова: река, отбор воды, уровень воды, расход воды, гидрологический режим, бассейн реки. 